\title{
Evolution Mechanism and Stability Analysis of Roof Deflection of Composite Structure Roadway Under Dynamic Load Disturbance
}

\section{Zequan Sun ( $\sim$ s17685545796@163.com )}

Shandong University of Science and Technology https://orcid.org/0000-0003-0904-5865

Hao Feng

Shandong University of Science and Technology

\section{Wenhai Wang}

Shandong University of Science and Technology

\section{Tao Guo}

Shandong University of Science and Technology

\section{Qingwei Wang}

Shandong University of Science and Technology

\section{Peng Tang}

Shandong University of Science and Technology

\section{Research Article}

Keywords: Composite roof roadway, dynamic load disturbance, similar simulation, surrounding rock stability

Posted Date: June 2nd, 2021

DOl: https://doi.org/10.21203/rs.3.rs-546156/v1

License: (c) (i) This work is licensed under a Creative Commons Attribution 4.0 International License. Read Full License

Version of Record: A version of this preprint was published at Geotechnical and Geological Engineering on July 25th, 2021. See the published version at https://doi.org/10.1007/s10706-021-01945-2. 


\title{
Evolution mechanism and stability analysis of roof deflection of composite structure roadway under dynamic load disturbance
}

\author{
Zequan Sun ${ }^{1,}$, Hao Feng ${ }^{1}$ ' Wenhai Wang ${ }^{1 *}$, Tao Guo ${ }^{1}$ Qingwei Wang ${ }^{1}$ Peng Tang ${ }^{1}$ \\ (1. State Key Laboratory of Mining Disaster Prevention and Control, Shandong University of Science and Technology, Qingdao, \\ 266590, China) \\ * Correspondence: s17685545796@163.com; wenhaiwang2020@163.com
}

\section{Abstract:}

The lithology of the roof of the mining roadway is compound and the thickness of each layer varies greatly, and it is disturbed by dynamic load all the year round. The above factors have caused a huge difference in the stability of the roadway surrounding rock. Taking the 11020 lower tunnel of a mine in Henan Province as the engineering geological background, using on-site investigation, formula derivation, numerical simulation and other methods, the composite roof roadway model group was established to study the deflection evolution characteristics of the surrounding rock under dynamic load disturbance, and summarize the plastic zone of the surrounding rock of the roadway Deformation and evolution of roof surrounding rock to evaluate the stability of surrounding rock with different roof structures. The research results show that the change of the roof surrounding rock structure will also lead to the change of the center deflection of the roadway roof. Therefore, the center deflection of the surrounding rock of various roof composite structures is different, and the deflection is the most direct indicator of the : jility of the surrounding rock. The center deflection $\left(\omega_{0}\right)$ the soft rock type is the largest, the center deflection $\left(\omega_{0}\right)$ of the upper soft and the lower hard type, and the soft and hard type is larger, and the sof $1 d$ hard progressive type, thin, hard and thick soft type $\left(\omega_{0}\right)$ is the smallest, and the dynamic load The relationship between the magnitude of deflection before and after the disturbance is consistent. By constructing a composite roof roadway numerical model group,

By constructing a composite roof roadway numerical model group, using the plastic failure zone of the roadway as the evaluation standard, the surrounding rock stability is evaluated and divided, and then the cross-point field measurement method is used to verify the stability of the surrounding rock on the roof of different composite structures. And the development of composite roof roadway surrounding rock deformation and failure mechanism and numerical simulation method has important theoretical significance and practical value for the analysis and control of composite roof roadway surrounding rock stability.

Key words: Composite roof roadway; dynamic load disturbance;similar simulation;surrounding rock stability

\section{Introduction}

The total number of newly excavated roadways around the world is tens of thousands of meters long. Coal resources are generally found in sedimentary strata. The roof of roadways is often composed of surrounding rocks of different lithologies, and the roles of each rock layers in underground activities are different. There are structurally weak surfaces between soft and hard rock layers. A single rock layer is generally thin and has poor interlayer bonding. The deformation of the lower and upper rock layers is not synchronized, and separation between the rock layers is prone to occur. The soft and hard interbeds lead to significant differences in the deformation of the surrounding rock of roadways with different composite structures. Rock layers with large thickness and relatively hard lithology play a controlling role in overburden movement, while rock layers with smaller thickness and weak lithology mostly play a loading role in overburden movement. The deflection of the key layer in the composite roof structure dominates the law and state of the overlying rock movement, and is very important to the stability of the surrounding rock of the roadway.

Liu Hongtao(2011) determined the size of the roof fall risk in different areas of the composite roof roadway by studying the proportion of the height of the stable rock strata in the roadway with composite roof, and established a roadway roof fall risk area identification system. Jia Peng(2006) used RFPA software to analyze 
the two factors affecting the surrounding rock deformation of layered roof roadway with the same lithology, which are the lateral pressure coefficient and the thick-span ratio. Sofianos A. L. $(1988,1996)$ and Lin Chongde(2000) used the discrete element method to analyze the deformation and failure laws of the layered roof after being supported by bolts. Jiang Lishuai(2014) used UDEC software to analyze the failure characteristics of the surrounding rock of the composite layered roof roadway, and based on the displacement of the bolt and cable to classify the hidden danger of the roadway surrounding rock roof fall in detail. The above scholars have made an in-depth summary of the failure law of the surrounding rock of the composite roof roadway without dynamic load disturbance. However, single-cycle or multiple-cycle dynamic loads of different energy levels will be released in the roadway interrupted layer slippage, the basic top rock beam breakage, and the impact of mining on the working face. Therefore, the study on the failure law of surrounding rock of composite roof roadway under dynamic load disturbance has far-reaching significance. Therefore, the study on the failure law of surrounding rock of composite roof roadway under dynamic load disturbance has far-reaching significance.

With the depletion of shallow coal resources, the depth and intensity of coal mining are increasing. In recent years, deep mining has gradually become the norm in the development of coal resources. However, as the buried depth of the roadway increases year by year, stress environments become more complex, rockburst have increased in frequency and intensity. In particular, deep roadway is more prone to dynamic disasters such as rock burst under the disturbance of dynamic load, which poses a huge threat to coal mine safety production. Dynamic pressure roadways account for $80 \%$ of engineering roadways. Affected by dynamic events such as violent movement of the working face, overburden rupture, and fault activation, the dynamic pressure roadway will be subject to high frequency, strong load, and dynamic load disturbances of multiple causes for a long time during the service life of the dynamic pressure((He 2009, Liu 2010, Chen 2016, Wang 2016). The surrounding rock of the roadway is subjected to the effect of "high stress-strong dynamic load", and the stress state of the surrounding rock usually reaches or approaches the long-term strength of the surrounding $\operatorname{rock}(Z h a n g$ 2009, Gao 2007). At this time, the occurrence of dynamic load disturbance may directly induce severe deformation of the surrounding rock of the roadway in a short time, and the destruction of surrounding rock will cause catastrophic failure of the roadway. On the other hand, high-frequency and low-energy dynamic load disturbances will also cause further damage and cracking of the surrounding rock of the roadway, decrease the stability of the surrounding rock of the roadway, and finally cause the time-space evolution induced instability of the roadway. When the structure above the coal seam is a multi-layer overlying rock structure, a large area of free space appears under the roof after the working face is mined, and the elastic energy accumulated in the coal and rock mass is greatly increased. When a dynamic event occurs, the original rock stress field interacts with the dynamic energy released by the dynamic event, which exceeds the load strength that the coal and rock mass can withstand, which will cause large-scale deformation of the surrounding rock of the roadway. For example, the 103 working face of Hongqinghe Coal Mine was affected by thick roof and single side goaf. During the mining period, there was a secondary dynamic manifestation event, and production was suspended after November 30, 2018. There is a multi-layer thick sandstone roof above the 3102 working face of Menkeqing Coal Mine in Inner Mongolia. Without adjustment in the previous period, the pillar width of the coal pillars left in the 3101 goaf is $35 \mathrm{~m}$. Multiple dynamic manifestations occurred on the working face due to the coupling effect of the above-mentioned "roof $\sim$ coal pillar". All of the above working faces have the characteristics of large mining depth, composite structure of roadway roof, and frequent dynamic events, which factors have had a huge impact on the development and utilization of coal resources.

Chang Jucai(2009) used FLAC software to analyze the surrounding rock stress, displacement field changes and failure characteristics before and after deep roadway excavation.

Kang Hongpu(2009) used FLAC3D software to analyzed the stress, displacement and failure zone condition around the tunneling face, and studied the 
distribution characteristics of the bolt support stress field near the excavation face and the control function of the roof of the empty roof range.

Aiming at the control problems of deep high ground stress, large section, and thick-top coal roadway surrounding rock, Xiao Tongqiang(2011) used theoretical analysis, numerical calculation and other methods to study its deformation and failure mechanism and its control technology.

Meng Qingbin(2012) used FLAC3D to analyze the rheological deformation laws of the roof, floor and both sides of the soft rock roadway surrounding rock under high stress.

Li Jie(2012) uses the elastic-brittle constitutive model and slip failure theory to analyze the stress distribution and deformation failure mechanism of the deep surrounding rock, and uses the calculation model considering expansion to obtain the conditions for the tensile fracture of the surrounding rock.

Li Weiteng(2013) carried out a large-scale geomechanical model test based on the engineering background of the thick-top coal roadway in the 1,000-meter deep mine of Zhaolou Coal Mine, and studied the surrounding rock displacement, stress evolution law and deformation failure mechanism of deep thick top coal roadway under the action of anchor cable beam support system.

Zhang Hongjun(2016) aimed at the characteristics of large deformation, fast convergence rate, and long continuous deformation time of the surrounding rock after excavation and support of deep high-stress mining roadways. Taking a coal roadway in a mining face as the research background, the failure characteristics and failure mechanism of the roadway are analyzed in detail.

Xie Guangxiang(2016) comprehensively used numerical simulation, theoretical analysis and on-site observation of the roadway to thoroughly study the mechanical characteristics of the roadway surrounding rock and its influence on the stability of the surrounding rock.

Taking a coal mining roadway in Huainan mining area as an example, based on the block discrete element method, Zhang Chenghui(2017) established a numerical model of the surrounding rock of the deep mining roadway, and simulated the deformation characteristics of the surrounding rock during the excavation process.

Qi Qingxin's(2010) research found that the main conditions for deep dynamic and static load superimposed rockburst occurred. Due to the large buried depth, generally exceeding $650 \mathrm{~m}$, the dead weight stress and horizontal structural stress are sufficient. However, even under the superposition of various local static loads, the critical load for impact start cannot be reached, and the surrounding rock can be destabilized and deformed under small external dynamic load disturbance. In summary, domestic and international scholars have used on-site measurement, theoretical research, formula derivation, and numerical simulation to gain a deeper understanding of the deformation law of composite roof surrounding rock without dynamic load disturbance and the disaster mechanism of single roof structure roadway under dynamic load disturbance. The research has formed a complete system of deformation and failure of surrounding rock. However, the comparative study on the deflection evolution mechanism and stability of the surrounding rock of the composite roof roadway under the disturbance of the dynamic load is left blank. Therefore, the investigation of the composite roof roadway in the Zhaogu mining area in Henan is carried out. The borehole spy device is used to detect the roof rock strata structure are shown in Figure 1. Two mining roadways in the 11020 working face of $2_{1}$ coal seam in a certain mine in Henan are selected. The two ribs of the roadways have high coal strength, less damage but complex roof conditions. 

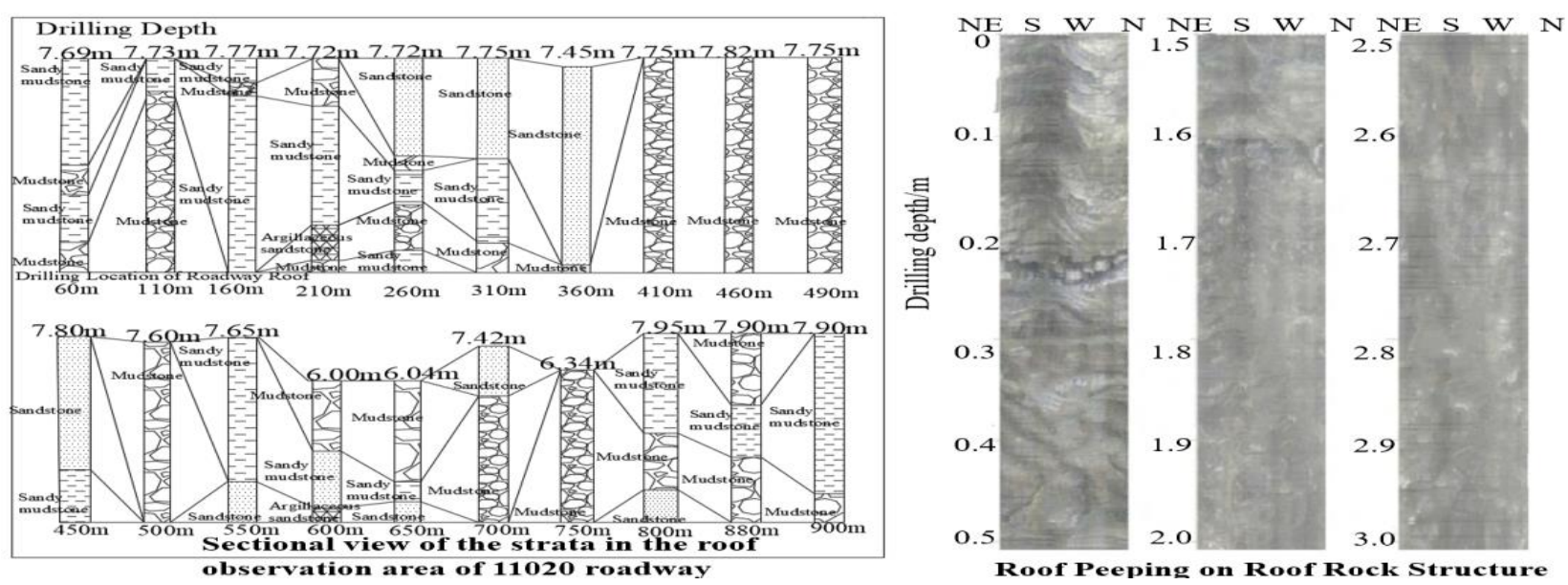

Fig.1 11020 roadway roof composite structure

The roof lithology mainly includes soft mudstone, medium-strength sandy mudstone and a small amount of hard sandstone.The roof lithology and thickness of the same roadway vary greatly, and there are many types of roof composite structures, the roof pressure is high, and various dynamic events frequently occur during the mining period. Therefore, the 11020 working face is a typical composite roof roadway under dynamic load disturbance. The 11020 working face is selected as the engineering case background. Through theoretical analysis, numerical simulation and field investigation, the comparative study of the roof deflection evolution mechanism and surrounding rock stability of composite roof roadway under dynamic load disturbance has important theoretical significance and practical value.

\section{Engineering case}

\subsection{Engineering situations}

The two mining roadways in the 11020 working face of $2_{1}$ coal seam of a certain mine in Henan are typical composite layered roof roadways. The two ribs of the coal body have high strength, but the roof conditions are complicated. The roadways were used to detect the structure of the roof slab of the roadway with a borehole spy device, and a cross-sectional view of the roof slab of the sample roadway was drawn. The lithology of the roof of the roadway is mainly soft mudstone, sandy mudstone, and sandstone. The lithology and thickness of the roof of the same roadway vary greatly. There are many types of roof rock formations, which leads to huge differences in the stability of the roof.
Based on the columnar and combined forms of boreholes(Jiang 2014) obtained from the exploration of the rock strata structure of the roadway and the large amount of field measurement data of the composite layered roof structure by predecessors, the composite roof structure is divided into five typical structure types: (1)The weak rock type of roof is composed of mudstone and coal rock; (2)The bottom soft and top hard type of roof is composed of soft mudstone and hard sandstone from shallow to deep; (3)The hard and soft type of roof is composed of sandstone and mudstone; (4)The soft and hard progressive type of roof is composed of mudstone or top coal, sandy mudstone and sandstone; (5)Thin hard thick soft type of roof is composed of sandstone and mudstone.

The 11020 lower groove is excavated along the roof, and the full section is excavated at one time. The designed rectangular section is $4.8 \mathrm{~m} \times 3.8 \mathrm{~m}$ wide and $3.8 \mathrm{~m}$ high, with a coal seam of about $3 \mathrm{~m}$ left on the top. The roadway is supported by bolting net cable beams and $\mathrm{W}$-shaped steel belts. The roof bolts are supported by high-strength rebar bolts, the spacing between rows is $800 \mathrm{~mm} \times 1000 \mathrm{~mm}$, the square tray size is $150 \mathrm{~mm} \times 150 \mathrm{~mm} \times 10 \mathrm{~mm}$, the row spacing between roof cables is $1300 \mathrm{~mm} \times 1000 \mathrm{~mm}$, and the cables are U29 cable beams as a top beam. The two ribs use non-longitudinal reinforcement and other strong rebar bolts, the spacing between rows is $800 \mathrm{~mm} \times 1000 \mathrm{~mm}$, and the size of the W-shaped steel strip is $1900 \mathrm{~mm} \times 280 \mathrm{~mm} \times 5 \mathrm{~mm}$. The specific supporting parameters are shown in Figure 2. 


\section{Roadway support section diagram}

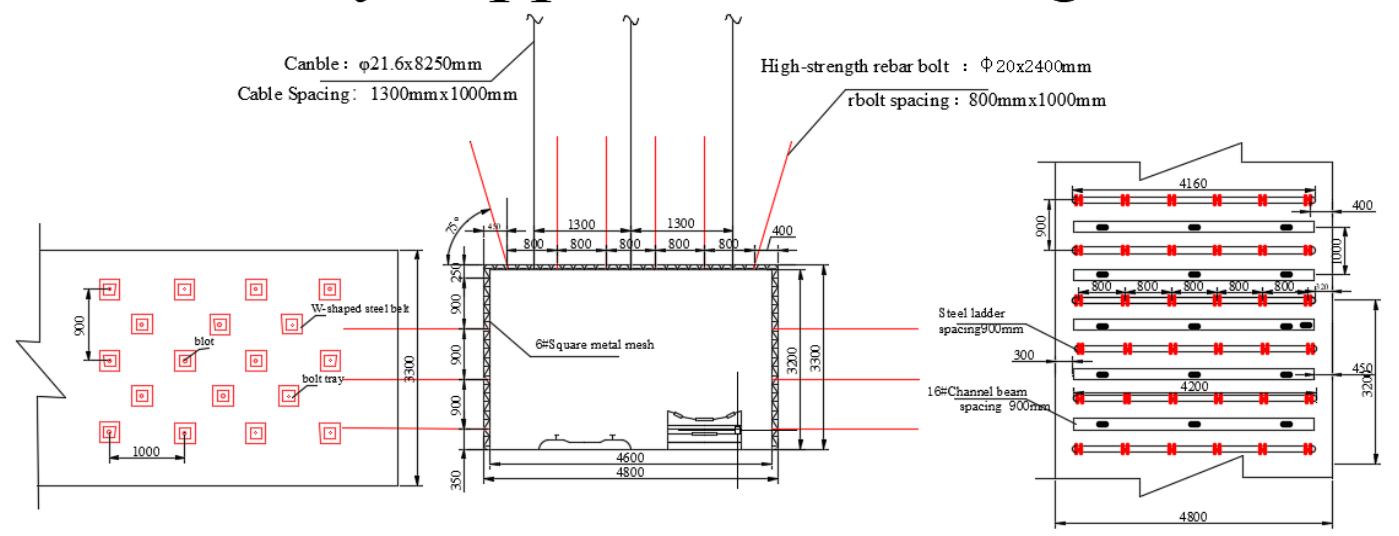

Fig.2 Roadway section size and support scheme

\subsection{General Situation of Deformation and} Failure of Surrounding Rock in 11020 Roadway

It can be seen from Figure 3 that under the action of high ground stress, the roof of the original roadway section has sunk severely to $1.5 \mathrm{~m}$, the two ribs of the roadway are extruded seriously, and the roadway section area is greatly reduced. According to field measurements, the minimum width of the roadway section is $2.16 \mathrm{~m}$, and the minimum height is $1.44 \mathrm{~m}$. The roadway

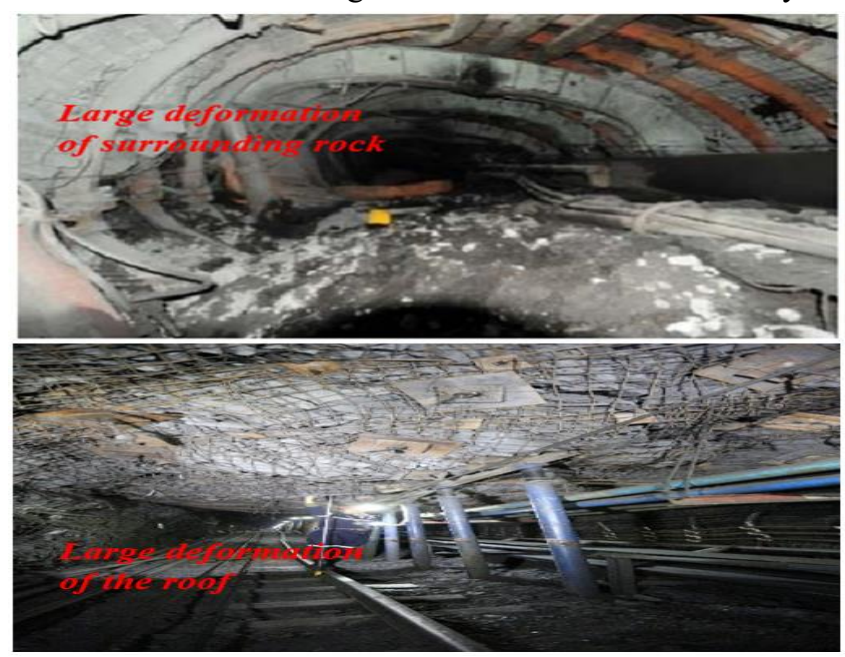

Fig.3 Failure condition of grooving on working face 11020

1.3 The relationship between the deflection of the surrounding rock of the composite roof

After the excavation of the composite roof roadway, the original three-dimensional stress state of the roadway was broken, and the surrounding rock stress was redistributed. The weaker surrounding rock first begins to deform and fail, and gradually expands to the depth of the surrounding rock, and finally the surrounding rock reaches a new state of stress balance. During this process, changes from a regular rectangular space to an irregular trapezoidal space. The bolts breaks, the roof rock beam deforms significantly, and the surrounding rock collapse often occurs. As a result, 11020 roadway surrounding rock deformed and broken seriously, joints and fissures developed obviously, and the stability of roadway surrounding rock was greatly reduced. Then, large roadway deformation and roof collapse were prone to cause roadway catastrophic instability and a large number of casualties and economic losses.

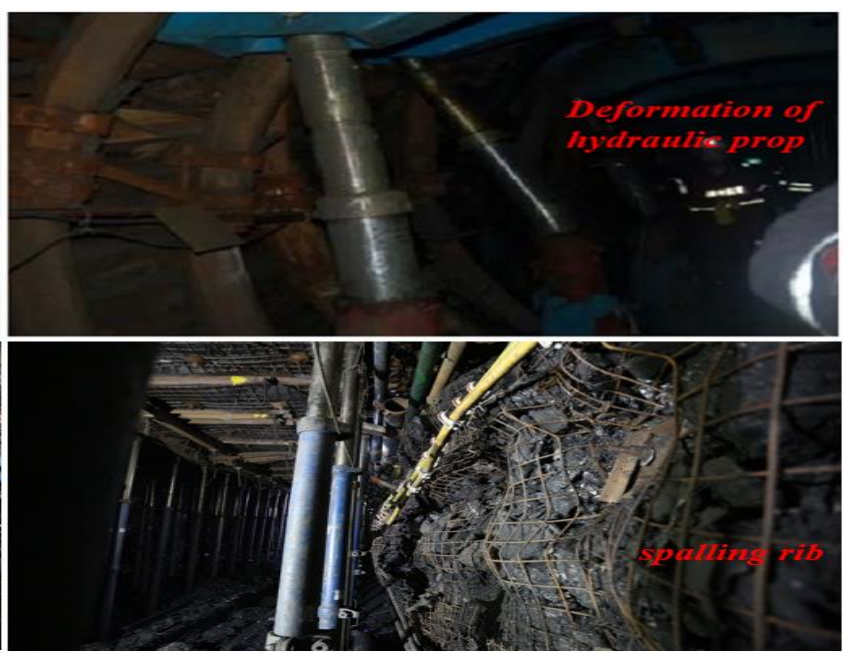

the roof of the roadway is separated from the layer and the stress is transferred to the surrounding rock, which can easily cause vertical stress concentration. In view of this mechanical feature of the composite roof roadway, the roof is partially simplified as an elastic rectangular plate to determine the deflection relationship of various composite structures. 


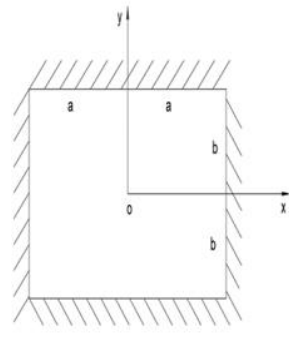

(a)

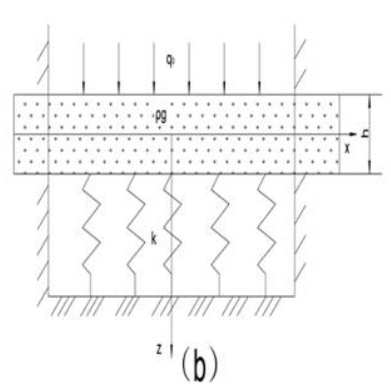

Fig.4 roof rock mass is simplified to a flat plate on a four-sided fixed-support equivalent elastic foundation

The roadway roof rock mass is regarded as an elastic rectangular flat plate with a fixed boundary. As shown in Figure 4, the local roof of the roadway is simplified to an elastic rectangular flat plate quantified by the oxyz coordinate system. Suppose the length of the elastic plate is $2 a$, the width is $2 b(b<a)$, the thickness is $\mathrm{h}$, the elastic modulus of the roof rock mass is $\mathrm{E}$, Poisson's ratio is V, the bulk density is $\rho$, and the tensile strength is $\left[\sigma_{s}\right]$. Assume that the overlying rock layer of the roadway is homogeneous and the pressure on the roof surface is a uniform load, as shown in the figure.

According to the flat plate bending theory based on elasticity (Qian 2010 Xun 1979, Yang 2005), the roof plate deformation displacement (deflection) $\omega(\mathrm{x}, \mathrm{y})$ can be obtained by the formula

$D \nabla^{4} \omega+k_{0} \omega=q$

Where $\mathrm{D}=$ The bending strength of the elastic plate, $D h^{3}=\frac{E}{\left[12\left(1-v^{2}\right)\right]}, k_{0}=$ Stress concentration factor.

The total uniform load $q$ acting on the top plate is formed by the superposition of $q_{z}$ and the self-weight load $\rho g h$ of the roof plate $q=q_{z}+\rho g h$.

The fixed condition of the boundary of the roof plate before deformation is: $\left.\omega\right|_{x=\mp a}=\left.0 \quad \omega\right|_{x=\mp b}=0$ $\left.\frac{\vartheta_{\omega}}{\vartheta_{x}}\right|_{\mathrm{x}=\mp \mathrm{a}}=\left.0 \frac{\vartheta_{\omega}}{\vartheta_{y}}\right|_{\mathrm{x}=\mp \mathrm{b}}=0$.

Except that the direct roof of the thin hard thick soft composite roof roadway is sandstone with $\mathrm{D}_{1}$ $=236.41 \mathrm{KN} / \mathrm{m}^{2}$, the direct roof of the other four composite roof roadways are all mudstone $\mathrm{D}_{2}$ $=63.81 \mathrm{KN} / \mathrm{m}^{2}$.

Taking into account the layered structure of the roof of 11020 working face, the uniform load on the exposed roof in the roadway is determined by formula (2)

$q_{z}=\frac{E_{1} h_{1}^{3}\left(\gamma_{1} h_{1}+\gamma_{2} h_{2}+\cdots+\gamma_{n} h_{n}\right)}{E_{1} h_{1}{ }^{3}+E_{2} h_{2}{ }^{3}+\cdots+E_{n} h_{n}{ }^{3}}$

Where $E_{n}=$ Young's modulus of the nth layer of the overburden, $\gamma_{n}=$ The volume force of the nth rock formation, $h_{n}=$ Thickness of the nth layer.

Considering the displacement and deformation (deflection) of the roof plate and the fixed boundary conditions, according to the suggestion of Wang(2008), the deflection $\omega$ has the following approximate solution

$\omega=\frac{\omega_{o}}{a^{4} b^{4}}\left(\chi^{2}-a^{2}\right)^{2}\left(y^{2}-b^{2}\right)^{2}$

Incorporating it into the Galerkin weak form equation of formula (3), the maximum deformation displacement (central deflection) of the midplane of the roof can be obtained as $\omega_{0}$

$$
\omega_{0}=\frac{441}{228} \cdot \frac{\mathrm{q}}{\left[2 \mathrm{k}_{0}+9 \mathrm{D}\left(7 / a^{4}+4 /\left(a^{2} \cdot b^{2}\right)+7 / b^{4}\right)\right]}
$$

Considering the situation of mining disturbance without adjacent working face, it is assumed that the stress concentration factor $k_{0}$ is 2 . The lithology under the roof of the five types of composite roof roadways is soft mudstone or hard sandstone and $\mathrm{D}_{1} \gg \mathrm{D}_{2}, k_{0}$ is a constant coefficient of 2 , and the uniform load of the five types of composite roof roadways is calculated as follows: The weak rock type is $q_{z}=0.014 \mathrm{MN} / \mathrm{m} / \mathrm{m}$, the bottom soft and top hard type is $q_{z}=0.035 \mathrm{MN} / \mathrm{m} / \mathrm{m}$, the hard and soft type is $q_{z}=0.092 \mathrm{MN} / \mathrm{m} / \mathrm{m}$, the soft and hard progressive type is $q_{z}=0.0028 \mathrm{MN} / \mathrm{m} / \mathrm{m}$, thin hard thick soft type is $q_{z}=0.0045 \mathrm{MN} / \mathrm{m} / \mathrm{m}$. Therefore, the total uniform load $q$ of the five types of composite roof roadways is: $0.1556 \mathrm{MN} / \mathrm{m} / \mathrm{m}$ for the weak rock type, $0.1058 \mathrm{MN} / \mathrm{m} / \mathrm{m}$ for the bottom soft and top hard, 0.1392 $\mathrm{MN} / \mathrm{m} / \mathrm{m}$ for the hard and soft type, $0.0752 \mathrm{MN} / \mathrm{m} / \mathrm{m}$ for the soft and hard progressive type, $0.1010 \mathrm{MN} / \mathrm{m} / \mathrm{m}$ for the thin hard thick soft type. Judge the size relationship of the roof deflection $\left(\omega_{0}\right)$ of the composite roof roadway through the uniform load $(q)$, the stress concentration factor $\left(k_{0}\right)$, the bending strength of the elastic plate (D) and formula 3. It is concluded that the center deflection $\left(\omega_{0}\right)$ of the weak rock type is the largest, the bottom soft and top hard type, and the hard and soft type is larger, and the soft and hard progressive type, the thin hard thick soft type are the smallest.

\section{Failure characteristics of surrounding rock of composite roof of roadway under disturbance of dynamic load}

\subsection{Numerical model and parameters}

According to the actual geological conditions of 11020 working face of a mine in Henan, FLAC3D numerical simulation software is used to construct a three-dimensional numerical model, as shown in Figure 5. In order to analyze and compare the influence of different composite roof structures on the failure characteristics of the surrounding rock of the roadway, according to the research of Jiang (2014), five groups of composite roof roadway models are established, which are weak rock type, bottom soft and top hard type, hard and soft type, soft and hard progressive type, and thin hard thick soft type. When determining the size of the numerical model, the following two aspects are mainly considered: minimize the influence of the model 
boundary on the deformation and stress of the geological structure, so the design model size $\mathrm{X} \times \mathrm{Y} \times \mathrm{Z}=50 \mathrm{~m} \times 100 \mathrm{~m} \times 50 \mathrm{~m}$. In order to avoid the boundary effect, the central part of the model is selected according to the actual situation of the site, and the buried depth of the roadway is set to $800 \mathrm{~m}$, the unit volume weight of the overlying strata is $0.025 \mathrm{MN} / \mathrm{m} 3$, and a vertical stress of $20 \mathrm{MPa}$ is applied to the top boundary of the model to simulate the weight of the overlying strata stress.

Table1. Mechanical parameters of rock mass

\begin{tabular}{cccccc}
\hline 岩性 & $\begin{array}{c}\gamma / \\
\left(\mathrm{kg} \cdot \mathrm{m}^{3}\right)\end{array}$ & $\begin{array}{c}K / \\
(\mathrm{Gpa})\end{array}$ & $\begin{array}{c}G / \\
(\mathrm{Gpa})\end{array}$ & $\begin{array}{c}\varphi / \\
\left({ }^{\circ}\right)\end{array}$ & $\begin{array}{c}\sigma / \\
(\mathrm{Mpa})\end{array}$ \\
\hline 砂岩 & 2800 & 18.3 & 11.5 & 37 & 4.3 \\
泥岩 & 2560 & 9.8 & 7.1 & 31 & 1.8 \\
$2_{1}$ 煤 & 1280 & 6.5 & 4.2 & 27 & 1.4 \\
砂质泥岩 & 2680 & 13.2 & 9.0 & 35 & 3.0 \\
\hline
\end{tabular}

According to Jiang Lishuai(2016) previous numerical simulation research, the original rock stress and boundary conditions are set, and the displacement and deformation are defined in the direction perpendicular to the periphery and bottom boundary of the model. For different lithological rock layers, different scale mechanical models are adopted, Sandstone and Sandy mudstone, which have higher strength, adopts the Mohr-coulomb model model.Mudstone, coal, and other lower-strength rock layers adopt the strain softening model,and the support simulation is carried out according to the actual on-site support plan. The five groups of models all use the same support Protection scheme, as shown in Figure 5. The size of the model data collection area is $\mathrm{X} \times \mathrm{Y} \times \mathrm{Z}=20 \mathrm{~m} \times 40 \mathrm{~m} \times 10 \mathrm{~m}$, and the mechanical parameters of the model rock mass are shown in Table 1. Substituting various rock parameters into the numerical model, and starting the iterative calculation to reach a static balance, the roadway is excavated and supported, and the roadway is simulated along the roof of the $2{ }_{1}$ coal seam with a strike length of $100 \mathrm{~m}$. After the roadway support is completed, the iterative calculation starts again. When the calculation result reaches the equilibrium simulation record again and enters the dynamic calculation, the dynamic load is applied to the top of the model. According to the dynamic load modeling method of Kaiser(2012), it is only applied to the top surface of the model, and the other surfaces of the model are set as static viscous boundary conditions to absorb the stress wave of dynamic load(Chen 2019) and prevent the secondary dynamic damage of the model caused by the internal refringent of stress wave, and the model results were recorded when $\mathrm{T}=0 \mathrm{~s}, \mathrm{~T}=0.02 \mathrm{~s}, \mathrm{~T}=0.04 \mathrm{~s}, \mathrm{~T}=0.06 \mathrm{~s}$, $\mathrm{T}=0.08 \mathrm{~s}$, and $\mathrm{T}=0.1 \mathrm{~s}$.

In underground mining activities, there are specific technical difficulties in determining the location of dynamic loads. Through the research of $\mathrm{x}$, understanding the location of the seismic source has an important impact on the surrounding rock of the roadway, and the most of the deep engineering dynamic disasters are mainly caused by the release of energy by the propagation of shock waves in the rock formation.Therefore, the propagation process of the dynamic load in the deep surrounding rock in the form of sine wave is used as the energy source of the dynamic load in the model, and the application method of the dynamic load is applied on the surface of the model rather than by the point source inside the model.This model uses the Rayleigh damping setting method. According to Zou (2011)and IDRISS I M (1973) calculation method of QUAD4 Rayleigh damping, it can be known that when the damping ratio is $5 \%$, the damping ratio at this time is the damping ratio independent of the dynamic frequency of the dynamic load. A damping ratio of $5 \%$ was selected to offset the uncontrollable energy transfer consumption caused by different depths of rocks and different frequencies of dynamic loads in the model ${ }^{[29-30]}$. The action time of the shock wave is a period of a single harmonic, that is, $\mathrm{T}=$ 1 / $\mathrm{f}$. In the numerical simulation, $\mathrm{f}=10 \mathrm{~Hz}$, the ppv wave speed is $2.5 \mathrm{~m} / \mathrm{s}$ (Sun 2020,He $2013 \mathrm{He} 2015$ ), The action period of the dynamic load can be known by calculation, $\mathrm{T}$ is $0.1 \mathrm{~s}$.Due to the occurrence of various dynamic events such as roadway excavation, mining activities, cover rock movement etc, the stress environment of the cover rock of the deep composite roof roadway has become more complicated.In order to study the influence of five compound roof structures of deep compound roof roadways on the deformation and failure characteristics of the surrounding rock of the roadway under dynamic load disturbance environment, the compound roof roadway was studied by $\mathrm{xx}$ : it is suggested to summarize the structural stability of different roof surrounding rock of compound roof roadway under dynamic load disturbance by the evolution law of plastic zone (Jiang 2016 Golsanami, N 2019) 


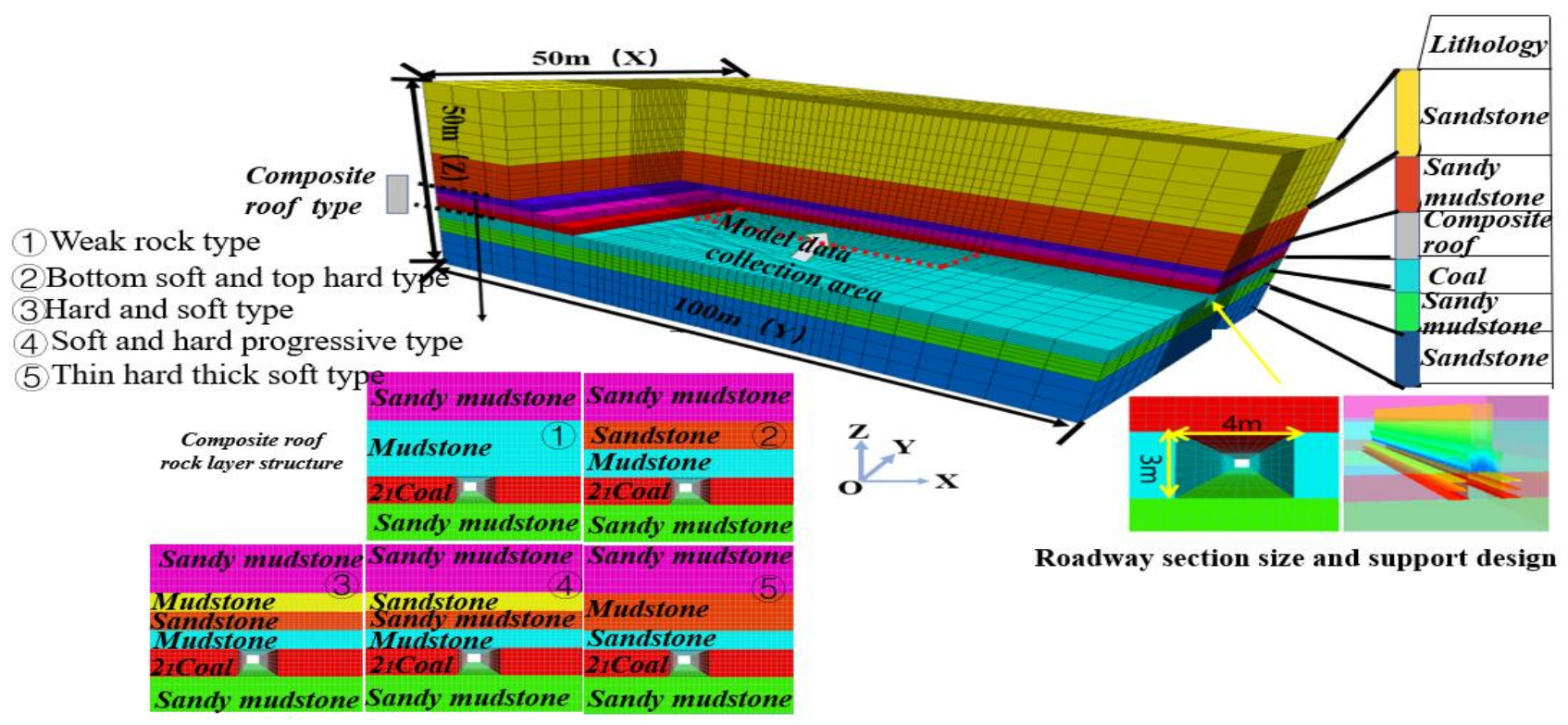

Fig.5 Numerical model strata and roadway support

\subsection{Evolution characteristics of roof deflection of compound structure roadway under dynamic load disturbance}

In order to study the influence of different compound roof lithological structures on the deformation of the surrounding rock of the roadway, based on the study of Kong(2019), a numerical model was established for five typical compound roof structures, and the surrounding rock deformation data of all roof units were collected and processed through the software data, A three-dimensional distribution map of the surrounding rock deformation of the roof along the direction of the roadway (y-axis) was established.As shown in Figure 6, before and after the dynamic load disturbance, the average deflection of the weak rock type is the largest, reaching $180 \mathrm{~mm}$ before the dynamic load disturbance and $300 \mathrm{~mm}$ after the disturbance. Soft and hard progressive type, thin hard thick soft type has the smallest average deflection, $30 \mathrm{~mm} \sim 70 \mathrm{~mm}$ before dynamic load disturbance, $110 \mathrm{~mm} \sim 140 \mathrm{~mm}$ after disturbance, and the maximum difference in average deflection of roadways with different compound roof lithology structures is $160 \mathrm{~mm}$ before disturbance and is $190 \mathrm{~mm}$ after disturbance, which shows that the roof lithological structure has a significant influence on the deflection of the roadway roof.

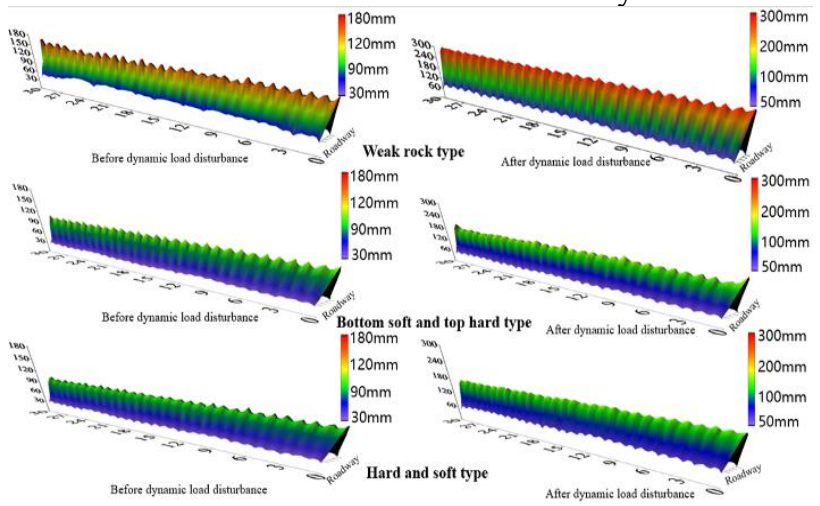

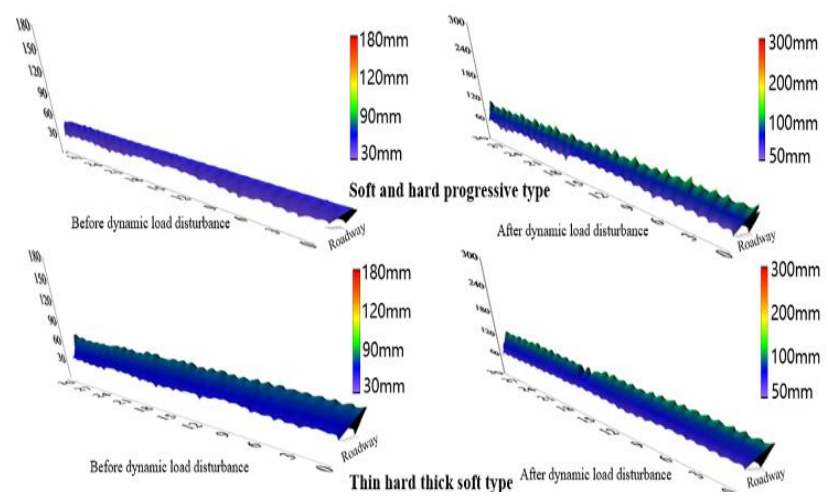

Fig.6 Evolution Law of Deflection of

Surrounding Rock of Composite Roof of Roadway

After the action of dynamic load, the impact on the average deflection of the roadway is also severe. The average deflection of the weak rock type roadway is increased by $120 \mathrm{~mm}$, the average deflection of the bottom soft and top hard type and the hard and soft type roadway increased by $70 \mathrm{~mm}$, and the soft and hard progressive type roadway increased by $40 \mathrm{~mm}$., The thin hard thick soft roadway has increased by $50 \mathrm{~mm}$. The smaller the deflection of the center of the roadway, the stronger the resistance of the roadway to dynamic load, the more complete the surrounding rock of the roadway

under the stress environment of dynamic load disturbance, and the stronger the stability of the roadway. The relationship between the deflection of the composite roof roadway before and after the dynamic load disturbance is consistent.

2.3 Deformation law of plastic zone in compound roof roadway under dynamic load 


\section{disturbance}

The numerical model of the compound roof roadway only has obvious differences in the structure of the roadway roof rock strata. The geological conditions, support design and other factors are consistent. Therefore, only the plastic zone of the roadway roof has a large difference in the distribution of the damage range. The ribs of the roadway and the plastic zone of floor of failure and development of the plastic zone is highly similar. The numerical model of the roadway is constructed by refining the gradient mesh to study the evolution characteristics of the plastic failure of the surrounding rock of the roadway under the different compound roof rock structure, and analyze the integrity of the surrounding rock of the different composite roof with the failure state and distribution law of the plastic zone.

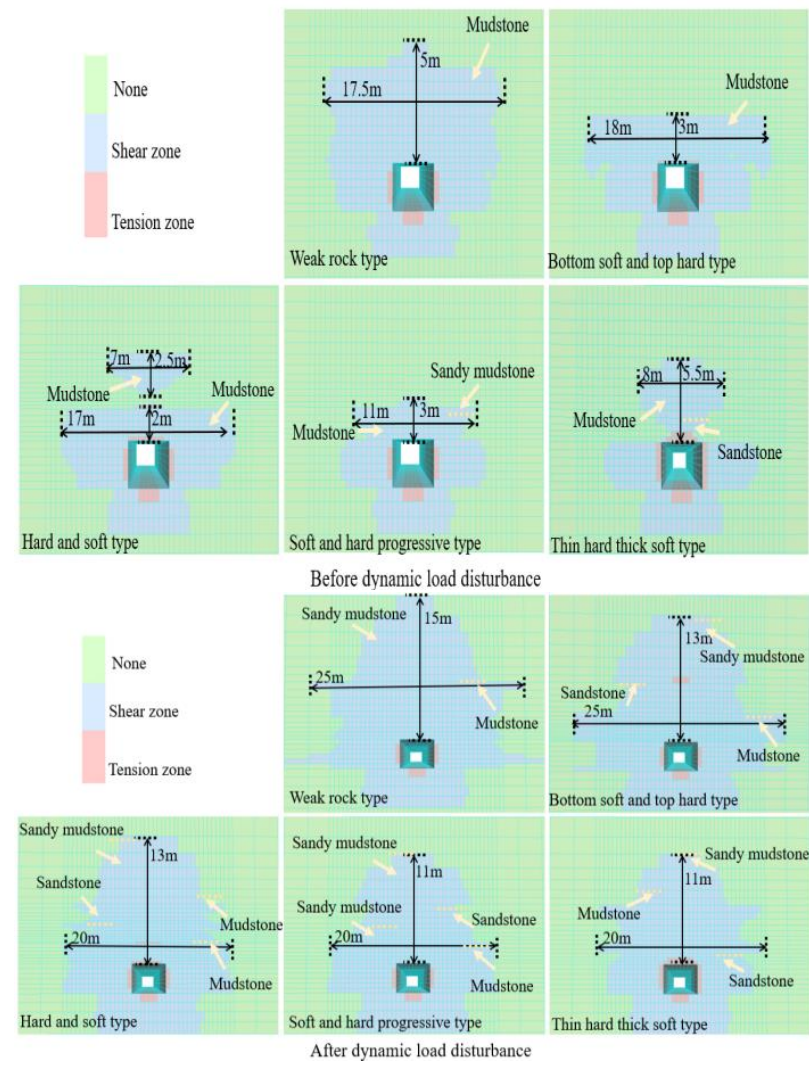

Fig.7 Evolution law of surrounding rock plastic

zone in composite roof roadway

It can be seen from Figure 7 that before the disturbance of the dynamic load, the roof plastic zone of the soft rock roadway has the largest damage range, reaching $5 \mathrm{~m}$ in the vertical direction and $17.5 \mathrm{~m}$ in the horizontal direction. The damage range of the bottom soft and top hard type roadway and the hard and soft roadway is significantly reduced compared with the weak rock type roadway, but the damage range of the plastic zone is still larger, and the failure of the roof plastic zone of the hard and soft type roadway shows delamination failure. Among all compound structures, the smallest plastic failure range is the soft and hard progressive type and the thin hard thick soft type, and the largest damage range is the weak rock type. Compared with the weak rock type, the soft and hard progressive type and the thin hard thick soft type in the plastic zone failure range of the roof surrounding rock are shortened by $40.0 \%(2 \mathrm{~m})$ in the vertical direction, and the thin hard thick soft type is increased by $9.0 \%(0.5 \%)$ in the vertical direction), shortened by $40.0 \%(2 \mathrm{~m})$ and $54.3 \%(9.5 \mathrm{~m})$ in the horizontal direction. The failure area of the plastic zone of the surrounding rock of the roadway is reduced.The soft and hard progressive type is $62.3 \%$ $\left(54.5 \mathrm{~m}^{2}\right)$, and the thin hard thick soft type is $49.7 \%$ $\left(43.5 \mathrm{~m}^{2}\right)$. After the dynamic load disturbance, the plastic zone failure area of the compound roof roadway increased significantly, the weak rock type increased by $157.1 \%\left(137.5 \mathrm{~m}^{2}\right)$, the bottom soft and top hard type increased by $501.9 \%\left(271 \mathrm{~m}^{2}\right)$, and the hard and soft type increased $404.9 \%\left(208.5 \mathrm{~m}^{2}\right)$, the soft and hard progressive type increased by $566.7 \%\left(187 \mathrm{~m}^{2}\right)$, and the thin hard thick soft type increased by $400 \%\left(176 \mathrm{~m}^{2}\right)$.

The plastic zone damage range of the weak rock type roadway is still the largest among the five types, and the soft and hard progressive type and the thin hard thick soft type roadways are still the smallest two of the five roof structures, The failure law of plastic zone in compound roof roadway after dynamic load disturbance is same as before the disturbance, no matter what kind of stress environment, the soft and hard progressive type and the thin hard thick soft type roadways have the smallest plastic zone damage range among the five types of compound roof roadways, and the integrity of the surrounding rock is stronger than the other three types, the soft and hard progressive type and the thin hard thick soft type roadways have the smallest plastic zone damage range among the five types of compound roof roadways, and the integrity of the surrounding rock is stronger than the other three types, while the weak rock type roadway is the largest in the plastic zone damage range among the five types of composite roof roadways, the lithology is weak, the surrounding rock is severely broken, and the integrity of the surrounding rock is the worst among the five roof structures.

\section{Field measurement and engineering verification}

The relative displacement of the roadway surface refers to the relative displacement of the roof and floor of the roadway and the rib within a certain period of time during the excavation of the roadway. The purpose is to clarify the changing law of the roadway surface displacement time, find out the relationship between the roadway surrounding rock movement and the support parameters, provide reliable basic data for reasonable support design, and provide quantitative indicators for accurately evaluating the support effect. Through the cross point method (as shown in Figure 8), a 300mm long and short coal pole with a void at the exposed end is installed at the midpoint of the rib and the roof and floor. A string is inserted into the hole. The roof and floor and the rib strings are tightened when measuring. Measure the 4 parameters shown in the figure with a steel tape, and calculate the absolute and relative approach distances respectively. 


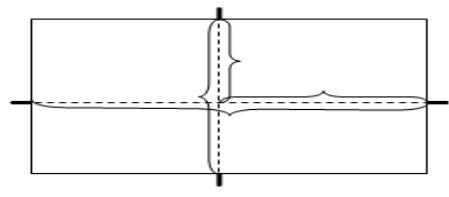

Fig.8 Layout drawing of surface displacement measuring points

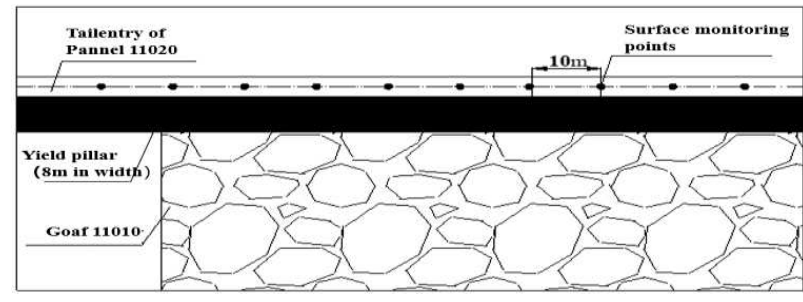

Fig.9 Location map of surface displacement station

16 measuring stations are arranged in 11020 roadway to observe the surface displacement of the roadway. The specific locations of the measuring points are shown in Figure 9 and Table 3.

Table. 3 Positions of measuring points for 11020 lower groove surface displacement

\begin{tabular}{cl}
\hline location & position $(\mathrm{m})$ \\
\hline One station & $370 \mathrm{~m}$ from the the roadway \\
Two station & $390 \mathrm{~m}$ from the the roadway \\
Three station & $410 \mathrm{~m}$ from the the roadway \\
Four station & $430 \mathrm{~m}$ from the the roadway \\
Five station & $450 \mathrm{~m}$ from the the roadway \\
Six station & $470 \mathrm{~m}$ from the the roadway \\
Severn station & $490 \mathrm{~m}$ from the the roadway \\
Aight station & $510 \mathrm{~m}$ from the the roadway \\
Nine station & $530 \mathrm{~m}$ from the the roadway \\
Ten station & $550 \mathrm{~m}$ from the the roadway \\
Eleven station & $570 \mathrm{~m}$ from the the roadway \\
Twelve station & $590 \mathrm{~m}$ from the the roadway \\
Thirteen Station & $610 \mathrm{~m}$ from the the roadway \\
Fourteen Station & $630 \mathrm{~m}$ from the the roadway \\
Fifteenth station & $650 \mathrm{~m}$ from the the roadway \\
Sixteen Station & $670 \mathrm{~m}$ from the the roadway
\end{tabular}

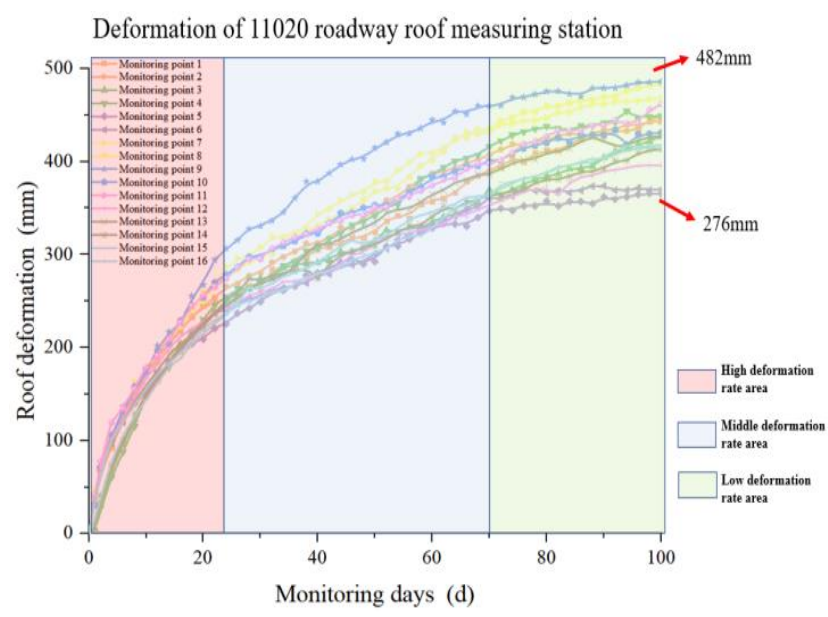

Fig.10 Monitoring diagram of the roof displacement of the text roadway

It can be seen from Figure 10 that the deformation trend of the roof displacement deformation curve obtained by setting all the roof measuring stations is the same in the 11020 roadway. In the high deformation rate range from $0 \mathrm{~d}$ to $20 \mathrm{~d}$, the roof deformation increases sharply to $207 \mathrm{~mm} \sim 251 \mathrm{~mm}$. In the middle deformation rate region of $20 \mathrm{~d} \sim 60 \mathrm{~d}$, the deformation rate of the roof gradually decreases, and finally in the low deformation rate region about $70 \mathrm{~d}$, the deformation rate decreases to a minimum and gradually stabilizes, and the deformation of the roof is about $482 \mathrm{~mm} \sim 276 \mathrm{~mm}$. Although the deformation trend of the roof deformation monitoring curve is the same, the difference in the amount of deformation after the roof is stabilized at 80 days is huge, and the difference in the amount of roof deformation reaches $206 \mathrm{~mm}$. Therefore, it can be seen that the change of the roadway roof rock structure has a significant impact on the roof deformation, To a great extent, it determines the stability of the surrounding rock of the roadway.

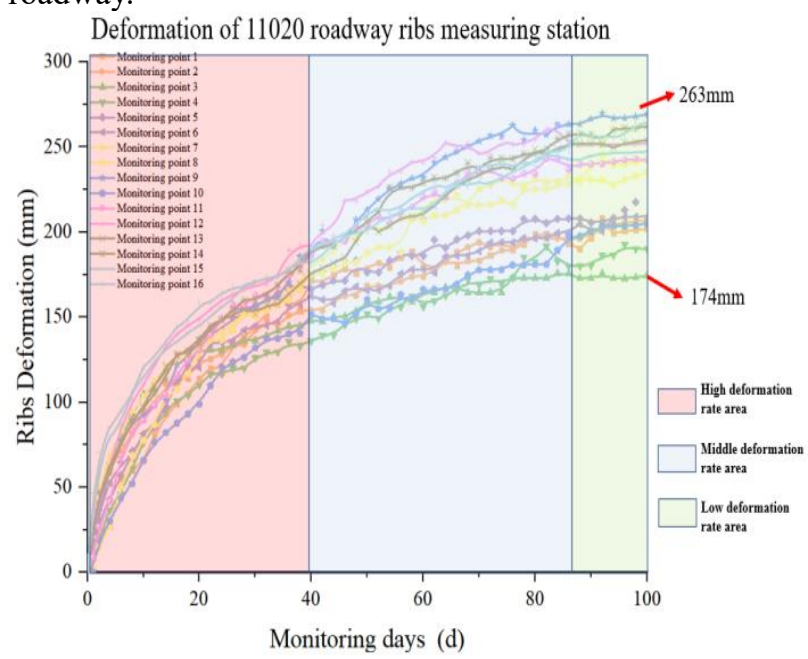

Fig.11 Monitoring diagram of the ribs displacement of the text roadway

It can be seen from Figure 11 that the deformation laws of the surrounding rock of the 11020 roadway rib are different from that of the roof surrounding rock, and the area of the high-deformation rate area has increased. Because the roadway siding is made of weak coal and rock, the strength of the rock mass itself is low. Therefore, the high deformation time of the surrounding rock of the bank is longer, and the stabilization time of the surrounding rock of the rib is longer than that of the roof. The deformation rate of the surrounding rock decreases to a minimum and stabilizes after 80 days, so the area of the low deformation rate area is also reduced.

Because the monitoring results of the 16 stations of 11020 roadway are quite different, the deformation difference of the roof surrounding rock reached $206 \mathrm{~mm}$, and the deformation difference of the rib surrounding rock has reached $81 \mathrm{~mm}$. Therefore, the monitoring curves with similar monitoring results are divided into groups. The dividing line of $450 \mathrm{~mm}$ and $400 \mathrm{~mm}$ is divided into four groups of monitoring curves of A, B, C and D.The lithology of the roof rock structure near the grouped measuring points is also measured. See Table 4 for the specific division. 
Table.4 Surface displacement observation statistics

\begin{tabular}{|c|c|c|c|c|c|c|c|c|}
\hline \multirow[b]{2}{*}{$\begin{array}{l}\text { Stat } \\
\text { ion } \\
\text { gro } \\
\text { upi } \\
\text { ng }\end{array}$} & \multirow[b]{2}{*}{$\begin{array}{c}\text { Roof } \\
\text { overly } \\
\text { ing } \\
\text { rock } \\
\text { compo } \\
\text { sition }\end{array}$} & \multirow[b]{2}{*}{$\begin{array}{l}\text { St } \\
\text { ati } \\
\text { on }\end{array}$} & \multicolumn{3}{|c|}{ Roof } & \multicolumn{3}{|c|}{ Ribs } \\
\hline & & & $\begin{array}{c}\text { Subs } \\
\text { iden } \\
\text { ce } \\
(\mathrm{mm} \\
\text { ) }\end{array}$ & $\begin{array}{l}\mathrm{V} \\
\mathrm{ma} \\
\mathrm{x} \\
(\mathrm{m} \\
\mathrm{m} / \\
\mathrm{d})\end{array}$ & $\begin{array}{l}\mathrm{V}_{\mathrm{av}} \\
\text { avera } \\
\mathrm{ge}(\mathrm{m} \\
\mathrm{m} / \mathrm{d})\end{array}$ & $\begin{array}{l}\text { Disp } \\
\text { lace } \\
\text { men } \\
\mathrm{t}(\mathrm{m} \\
\mathrm{m})\end{array}$ & $\begin{array}{l}\mathrm{V} \\
\mathrm{ma} \\
\mathrm{x} \\
(\mathrm{m} \\
\mathrm{m} / \\
\mathrm{d})\end{array}$ & $\begin{array}{c}\mathrm{V}_{\text {ava }} \\
\text { verage } \\
(\mathrm{mm} \\
/ \mathrm{d})\end{array}$ \\
\hline \multirow{4}{*}{ A } & \multirow{4}{*}{$\begin{array}{l}\text { Mainl } \\
\text { y soft } \\
\text { mudst } \\
\text { one }\end{array}$} & 7 & 468 & 21 & 3.6 & 235 & 9 & 1.8 \\
\hline & & 8 & 482 & 22 & 3.6 & 242 & 10 & 1.9 \\
\hline & & 9 & 487 & 22 & 3.7 & 259 & 11 & 2.0 \\
\hline & & 11 & 461 & 20 & 3.6 & 242 & 9 & 1.8 \\
\hline \multirow{4}{*}{ B } & \multirow{4}{*}{$\begin{array}{c}\text { Mainl } \\
y \\
\text { mudst } \\
\text { one } \\
\text { sandst } \\
\text { one } \\
\text { mud }\end{array}$} & 1 & 443 & 20 & 3.4 & 201 & 9 & 1.6 \\
\hline & & 2 & 447 & 17 & 3.4 & 206 & 10 & 1.6 \\
\hline & & 4 & 449 & 19 & 3.4 & 190 & 8 & 1.5 \\
\hline & & 10 & 431 & 17 & 3.3 & 205 & 10 & 1.6 \\
\hline \multirow{4}{*}{$\mathrm{C}$} & \multirow{4}{*}{$\begin{array}{c}\text { Mainl } \\
y \\
\text { sandst } \\
\text { one } \\
\text { and } \\
\text { mudst } \\
\text { one }\end{array}$} & 3 & 426 & 17 & 3.3 & 174 & 7 & 1.4 \\
\hline & & 13 & 427 & 20 & 3.4 & 254 & 11 & 1.9 \\
\hline & & 15 & 420 & 19 & 3.7 & 247 & 10 & 1.9 \\
\hline & & 16 & 414 & 20 & 3.2 & 264 & 9 & 2.0 \\
\hline \multirow{4}{*}{ D } & \multirow{4}{*}{$\begin{array}{l}\text { sandy } \\
\text { mudst } \\
\text { one } \\
\text { sandst } \\
\text { one is } \\
\text { mainl } \\
y\end{array}$} & 5 & 365 & 15 & 2.4 & 217 & 8 & 1.7 \\
\hline & & 6 & 370 & 17 & 2.5 & 209 & 9 & 1.6 \\
\hline & & 12 & 395 & 16 & 2.5 & 251 & 9 & 1.8 \\
\hline & & 14 & 413 & 17 & 2.7 & 236 & 10 & 2.0 \\
\hline
\end{tabular}

It can be seen from Table 4 that the deformation of the roof and the deformation of the rib are mutually influenced. The deformation of the roof is small, the deformation of the rib also becomes smaller, and the maximum deformation speed and the average deformation speed change with the change of the deformation amount. With the different locations of the measuring points, due to the multiple and complex features of the cover rock structure on the roof, the amount of deformation varies greatly among different measuring stations.

The deformation of the surrounding rock with soft mudstone as the cover rock is the largest, and the deformation of the surrounding rock mainly composed of mudstone, sandy mudstone and sandstone is the least, which is consistent with the numerical simulation results. The weak rock type has the worst surrounding rock integrity, and the soft and hard progressive type, the thin hard thick soft type surrounding rock has the best integrity. By collecting and comparing the geological information around the measuring station, it is found that the deformation curve of the measuring station with similar geological conditions is also similar.Therefore, it is particularly important to supplement the geological data of surrounding rock in time, classify and divide it, and then optimize the support plan according to the deformation characteristic area of the surrounding rock.

\section{Conclusion}

(1) Regarding the roof rock mass as an elastic slab, the relationship between the center deflection of the surrounding rock with different compound roof structures is solved by the flat plate bending theory, and through the numerical model to verify and obtain the size relationship of the center deflection of different compound roof structures under dynamic load disturbance, the result shows: The center deflection of the weak rock type is the largest, the center deflection of the bottom soft and top hard type and the hard and soft type is larger, the center deflection of the the soft and hard progressive type and the thin hard thick soft type is the smallest,and the relationship of deflection before and after dynamic load disturbance is consistent.

(2) Regardless of the stress environment, the soft and hard progressive type and the thin hard thick soft type have the smallest plastic zone damage range among the five compound roof roadways. The integrity of the surrounding rock is stronger than the other three, but the weak rock type roadway has the largest damage range in the plastic zone of the five types of composite roof roadways. The lithology is weak, the surrounding rock is severely broken, and the integrity of the surrounding rock is the worst among the five roof structures.

(3) The central deflection of the surrounding rock of the roof of the roadway, the distribution of the plastic zone of the surrounding rock, and the failure state are closely related to the structure of the roof rock. There are significant differences in the integrity of the surrounding rock of roadways with different roof composite structures. Therefore, the deformation and failure characteristics of the surrounding rock also change accordingly. The integrity of the surrounding rock of the weak rock type roadway is the worst, the soft and hard progressive type and the thin hard thick soft type roadways have stronger .surrounding rock integrity than the other three types. Through the surface displacement monitoring and roof surrounding rock observation of 11020 roadway, it is found that when the roof rock is mudstone, the deformation of the surrounding rock of the roadway is the largest, and when 
the roof rock is sandy mudstone and sandstone, the deformation of the surrounding rock is the smallest. The results remain consistent.

\section{References:}

[1] Liu HT, Ma NJ. (2011)High-risk area identification technology for coal mine roadway roof fall. Journal of China Coal Society (12),2043-2047.

[2] Jia P, Tang CN, Wang SH. (2006). Failure mechanism of layered rock roof of roadway. Journal of China Coal Society (01), 11-15.,2006,31(1):11-15.

[3] Sofianos A I,Kapenis A P. (1988)Numerical evaluation of the response in bending of an underground hard rock voussoir beam roof $\mathrm{J}]$. International Journal of Rock Mechanics and Mining Sciences and Geomechanics,1998,8:1071-1086.

[4] Sofians A I. (1996)Analysis and design of an underground hard rock voussoir beam roof $[\mathrm{J}]$. International Journalof Rock Mechanics and Mining Sciences and Geomechanics, 1996,2:153-166.

[5] Lin CD, Lu SL, Shi YW. (2000)Research on the supporting effect of bolts on the weak roof of coal roadways. Journal of China Coal Society (5), 482-485.

[6] Jiang LS, Ma NJ, Bai L, Li YJ, Zhang L. (2014). Deformation and failure characteristics of composite roof of roadway and classification of hidden roof failures. Journal of China Coal Society, 39(007), 1205-1211.,

[7] He MC, Xie HP, Peng SP Jiang YD. (2009) Research on Deep Mining, Rock Mass Mechanics. The 4th Deep Rock Mechanics and Engineering Disaster Control Symposium and China University of Mining and Technology (Beijing) Centennial Academic Conference..

[8] Liu QS, Gao W, Yuan L. (2010). Stability control theory and support technology and application of deep coal mine rock tunnels. Science Press.

[9] Chen DH, Hua XZ, Duan YW, Cheng SX. (2016). Simulation study on the tension and compression zone deformation and failure of the surrounding rock of the deep large deformation mining roadway. Rock and Soil Mechanics, 37(9), 2654-2662..

[10] Wang WJ, Yuan C, Yu WJ, Zhao YL, Peng WQ, Wu H et al. (2016). Deformation control technology for reserved surrounding rock of deep high-stress roadway. Journal of China Coal Society, 41(009), 2156-2164

[11] . Zhang N, Wang C, Gao MS, Zhao YM. (2009). Difficulty classification and control countermeasures for deep coal tunnel support in Huainan mining area. Chinese Journal of Rock Mechanics and Engineering, 28(012), 2421-2428.

[12] Gao Yanfa. (2007). Experimental study on rock rheology and its disturbance effect. Science Press.

[13] Gao YF, Xiao HQ, Wang B, Zhang YP. (2008). Experimental study on rock rheological disturbance effect and its constitutive relationship. Chinese Journal of Rock Mechanics and Engineering, 27(S1), 3180-3185.

[14] Chang JC, Xie GX. (2009). The mechanical characteristics of deep roadway surrounding rock and its stability control. Journal of China Coal Society (7), 881-886.

[15] Kang HP, Wang JH, Gao FQ. (2009). Stress distribution characteristics of surrounding rock in driving face and its relationship with support. Journal of China Coal Society (12), 1585-1593.

[16] Xiao Tongqiang, Bai Jianbiao, Wang Xiangyu, Chen Yong, \& Yu Yang. (2011). The principle and control of surrounding rock stability of deep large-section thick-top coal roadway. Rock and Soil Mechanics, 32(6), 1874-1880.

[17] Meng QB, Han LJ, Qiao WG, Lin DG, Lv YX. (2012). Research on deformation and failure characteristics of deep high-stress soft rock roadway. Journal of Mining and Safety Engineering, 29(4), 481-486. Mortazavi, A. , \& Tabatabaei Alavi, F. . (2013). A numerical study of the behavior of fully grouted rockbolts under dynamic loading. Soil Dynamics \& Earthquake Engineering, 54, 66-72.

[18] Li Jie, Song Chunming, Hu Xiao, Chen Wentao, \& Fan Pengxian. (2012). Analysis of deformation and failure mechanism of 
surrounding rock of deep roadway. Rock and Soil Mechanics (S2), 365-370..

[19] Li WT, Li SC, Wang Q, Ruan GQ, Zuo JZ, Liu WJ et al. (2013). Model test study on deformation and failure mechanism of surrounding rock of deep thick top coal roadway. Rock and Soil Mechanics (10), 114-123.

[20] Zhang HJ, Li HY, Li HW(2016). Damage mechanism and control technology of surrounding rock of deep mining roadway. Coal Mine Safety, v.47;No.505(09), 93-96.

[21] Xie GX, Li CM, Wang L. (2016). Mechanical characteristics and engineering practice of the stress shell of roadway surrounding rock. Journal of China Coal Society (12), 2986-2992

[22] Zhang CH, Shi C, Cha WH, Chen DH. (2017). Research on deformation test and numerical simulation of surrounding rock of deep roadway. Journal of Hebei University of Engineering: Natural Science Edition (04), 27-31.

[23] Qi QX, Li XL, Zhao SK. (2013). Theory and practice of rock burst stress control in coal mines. Coal Science and Technology, 41(006), 1-5. Kaiser, P.K., Cai, M. (2012) Design of rock support system under rockburst condition. J Rock Mech Geotech Eng 4(3): 215-227.

[24] Qian MG, Shi PW, Xu JL. (2010). Mine pressure and rock formation control. China University of Mining and Technology Press.

[25] Xu ZL. (1979). Elasticity. Volume I. People's Education Press.

[26] Yang Q, Chen X, Zhou WY. (2005). The elastoplastic mechanics foundation of geotechnical engineering reinforcement analysis. Rock and Soil Mechanics, 26(004), 553-557.

[27] Wang JA, Shang XC, Liu H, Hou ZY. (2008). Research on the failure mechanism and catastrophic collapse of the hard roof in the goaf. Journal of China Coal Society (08), 850-855.

[28] Jiang LS. (2016). Research on engineering rock mass degradation and surrounding rock control principles of large mining heights along goaf roadways. (Doctoral dissertation, China University of Mining and Technology (Beijing).
[29] Kaiser, P. K. , \& Ming, C. . (2012). Design of rock support system under rockburst condition. Journal of Rock Mechanics and Geotechnical Engineering(03), 215-227.

[30] Chen, S. J., Yin, D. W., Jiang, N., Wang, F., \& Guo, W. J. (2019). Simulation study on effects of loading rate on uniaxial compression failure of composite rock-coal layer. Geomechanics and Engineering, 17(4), 333-342.

[31] Zou D. G., Xu, B. Kong, X J.,. (2011)"Study of influence of determining Rayleigh damping coefficient on seismic response of high earth-rock dams." Rock and Soil Mechanics 32.3: 797-803.

[32] IDRISS I M, LYSMER J, HWANG R, (1973). QUAD4: a computer program for evaluating the seismic response of soil structures by variable damping finite element procedures[R]. Berkeley: University of California, .

[33] Sun Z, Jiang L , Jiang J , et al. (2020)Parametric Study on the Ground Control Effects of Rock Bolt Parameters under Dynamic and Static Coupling Loads[J]. Advances in Civil Engineering, , 2020(16):1-12.

[34] He Jiang. (2013). Research on the effect of coal mining dynamic load on coal and rock mass and the mechanism of inducement. (Doctoral dissertation, China University of Mining and Technology).

[35] He, J., Dou, L.-M., Cai, W., Li, Z.-L., \& Ding, Y.-L. (2015). In Situ Test Study of Characteristics of Coal Mining Dynamic Load. Shock and Vibration, 2015, 1-8. doi:10.1155/2015/121053.

[36] Jiang, L. , Sainoki, A. , Mitri, H. S. , Ma, N. , Liu, H. , \& Hao, Z. . (2016). Influence of fracture-induced weakening on coal mine gateroad stability. International Journal of Rock Mechanics and Mining ences, S1365160916300764.

[37] Golsanami, N. , Sun, J. , Liu, Y., Yan, W. , Lianjun, C. Jiang, L. , et al. (2019).

Distinguishing fractures from matrix pores based on the practical application of rock physics inversion and nmr data: a case study from an 
unconventional coal reservoir in china. Journal

of Natural Gas Science \& Engineering, 65,

145-167.

[38] Kong, P., Jiang, L., Shu, J. et al. (2019). Effect

of fracture heterogeneity on rock mass stability

in a highly heterogeneous underground roadway.

Rock Mechanics \& Rock 
Figures
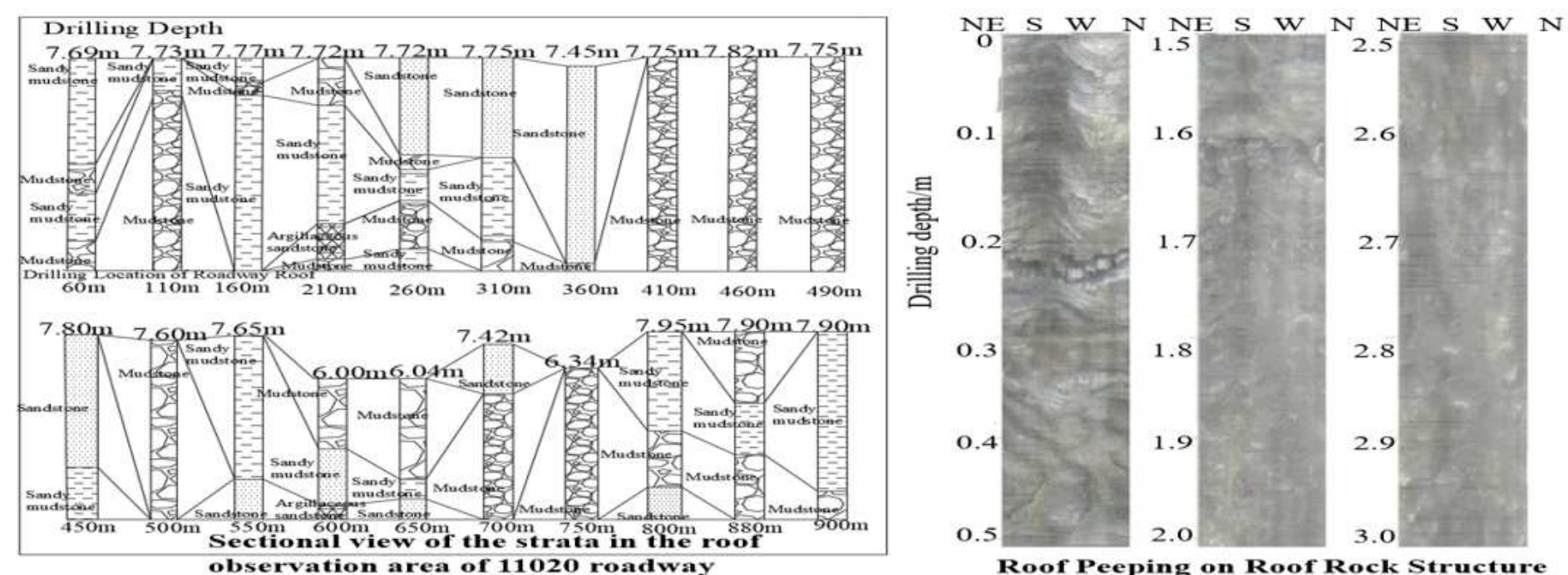

Figure 1

11020 roadway roof composite structure

\section{Roadway support section diagram}

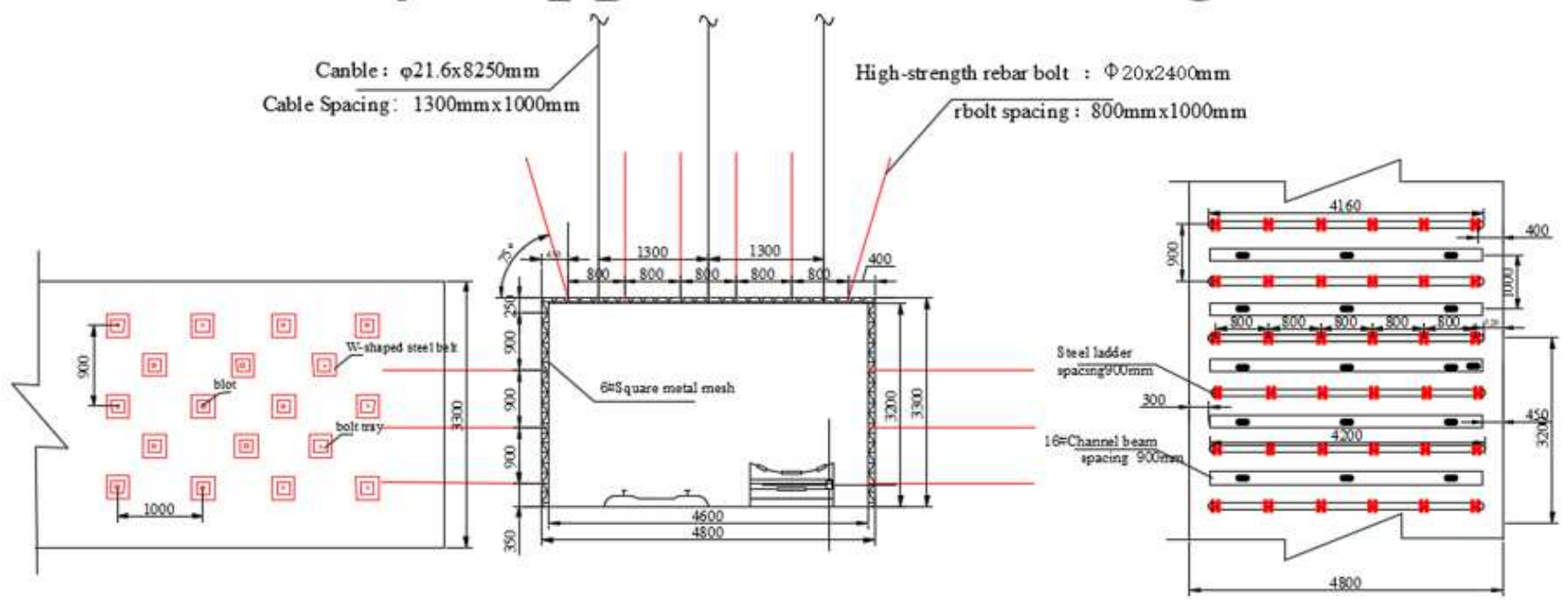

Figure 2

Roadway section size and support scheme 

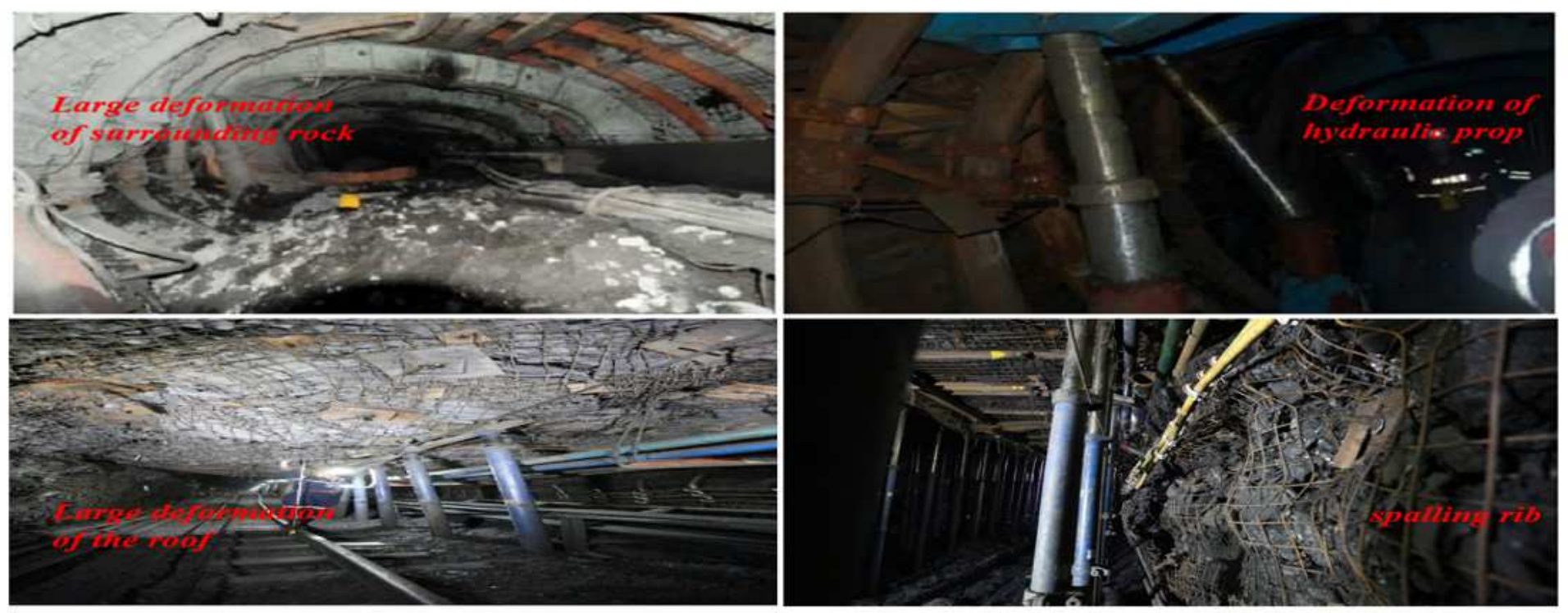

\section{Figure 3}

Failure condition of grooving on working face 11020

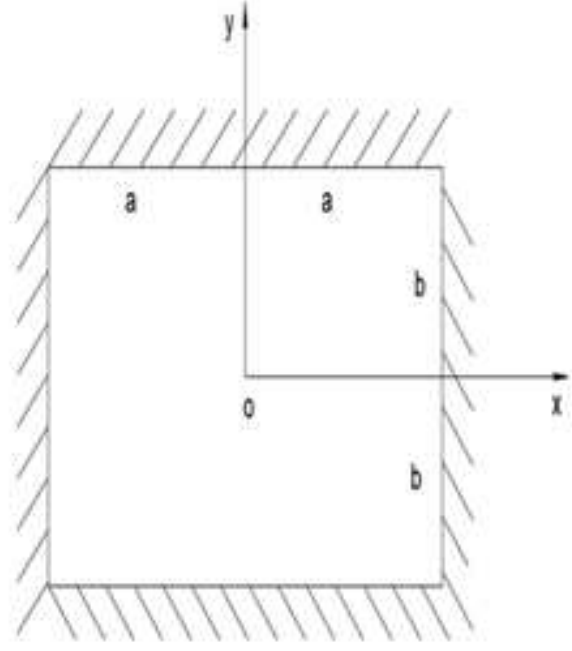

(a)

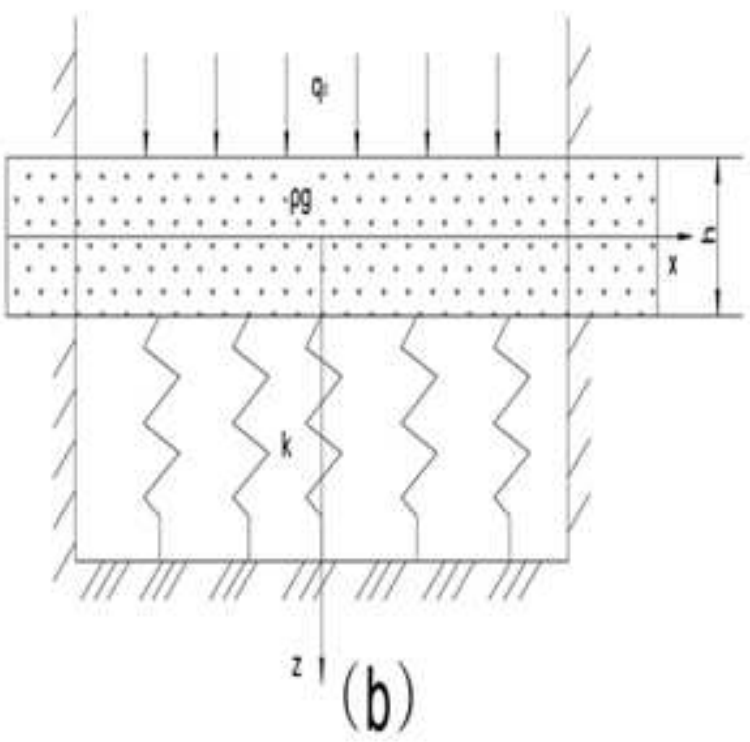

Figure 4

roof rock mass is simplified to a flat plate on a four-sided fixed-support equivalent elastic foundation 
(1) Weak rock type

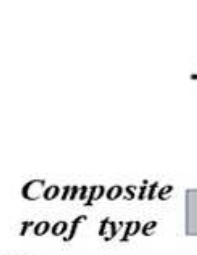

(2) Bottom soft and top hard ty

3 Hard and soft type

(4) Soft and hard progressive type

(5) Thin hard thick soft type Sandy mudstone Sandy mudstone

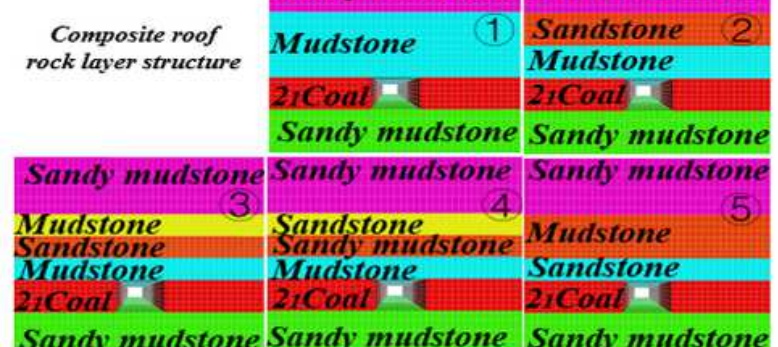

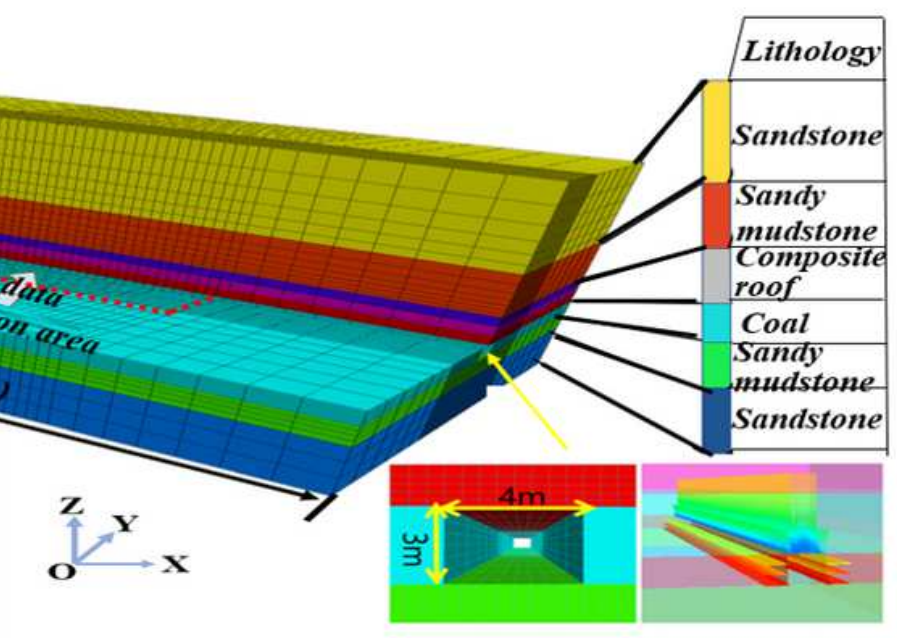

Roadway section size and support design

\section{Figure 5}

Numerical model strata and roadway support
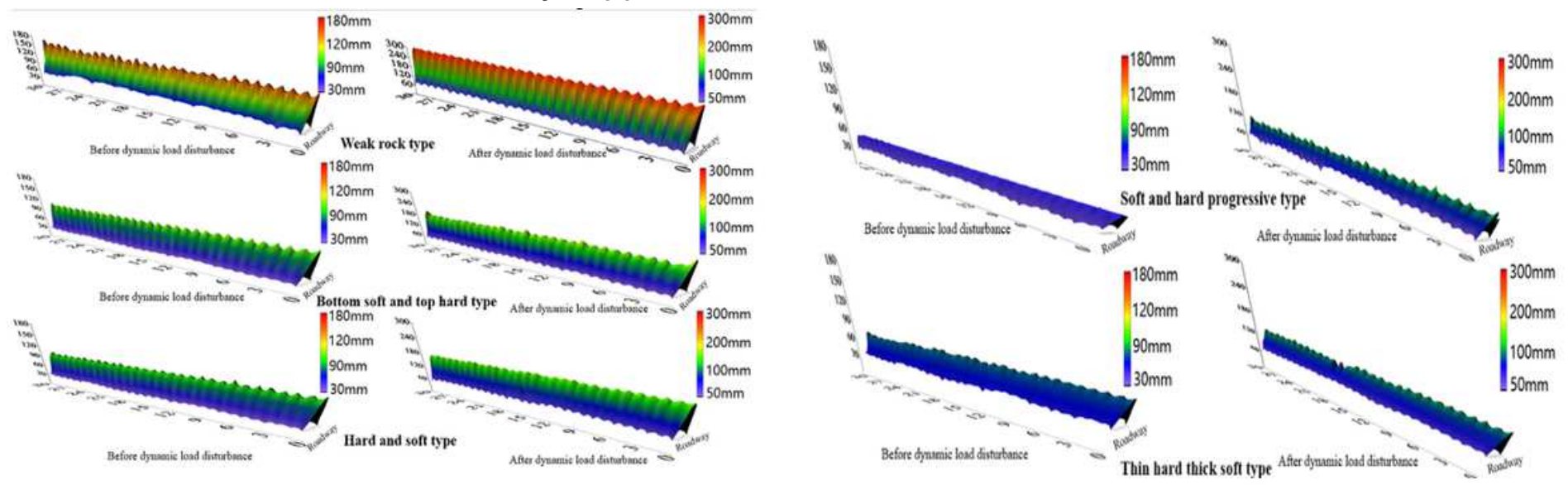

Figure 6

Evolution Law of Deflection of Surrounding Rock of Composite Roof of Roadway 


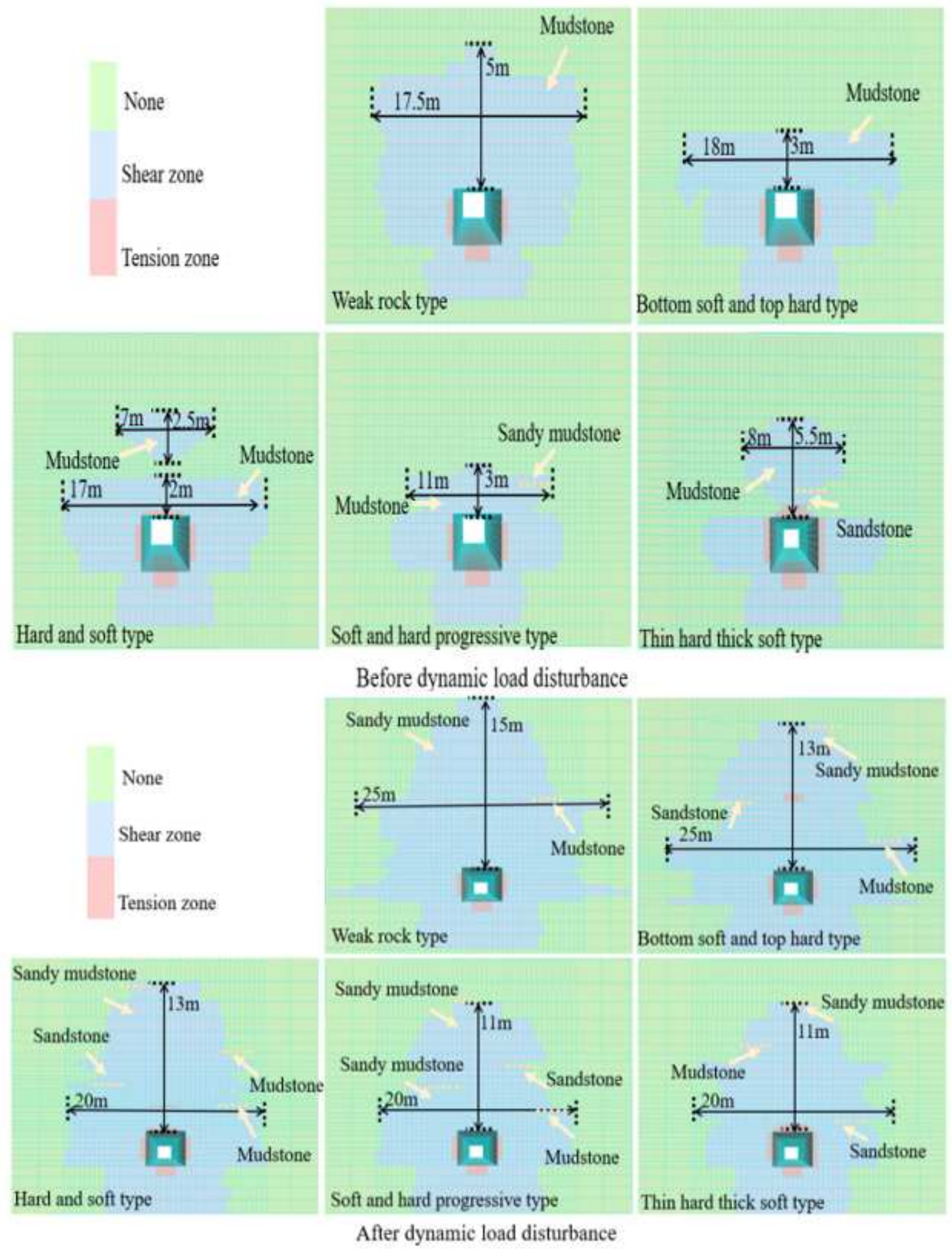

\section{Figure 7}

Evolution law of surrounding rock plastic zone in composite roof roadway 


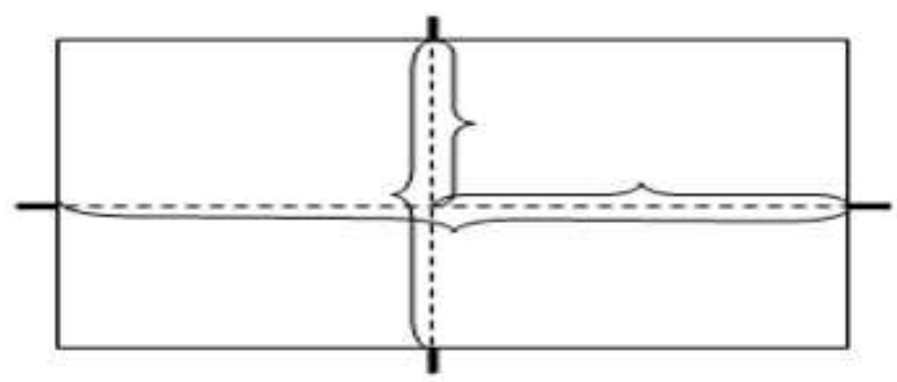

Figure 8

Layout drawing of surface displacement measuring points

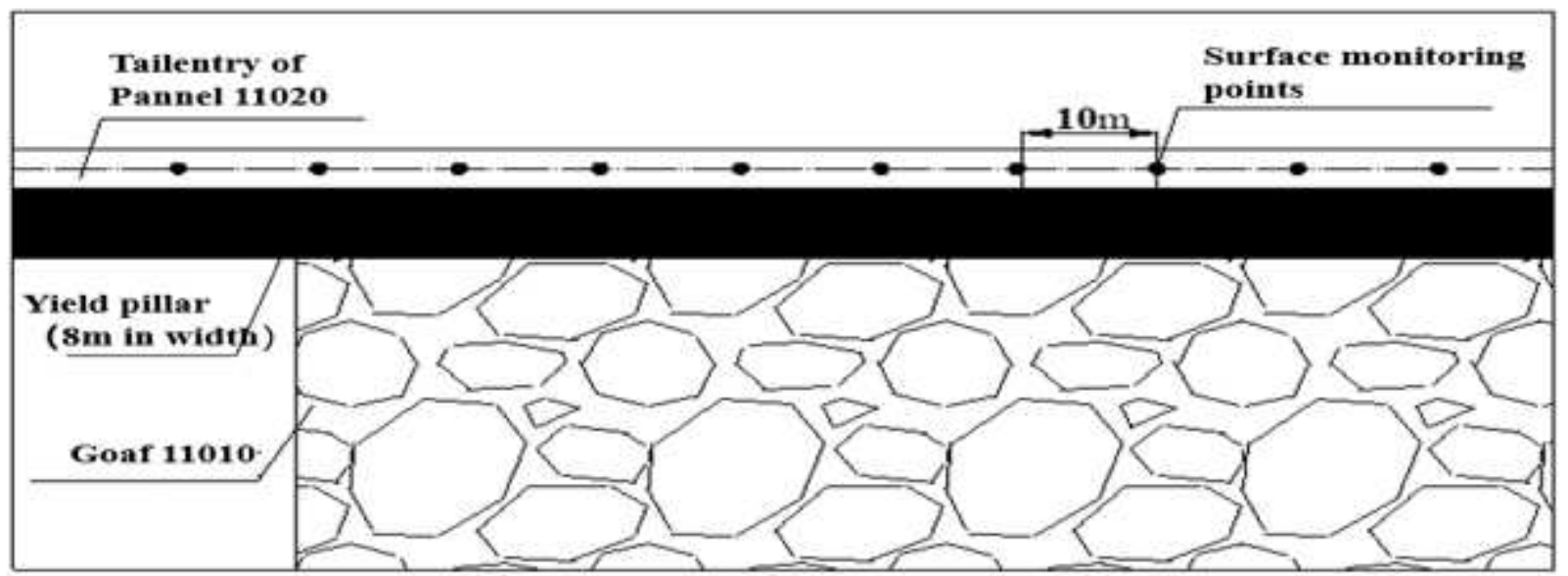

Figure 9

Location map of surface displacement station 


\section{Deformation of 11020 roadway roof measuring station}

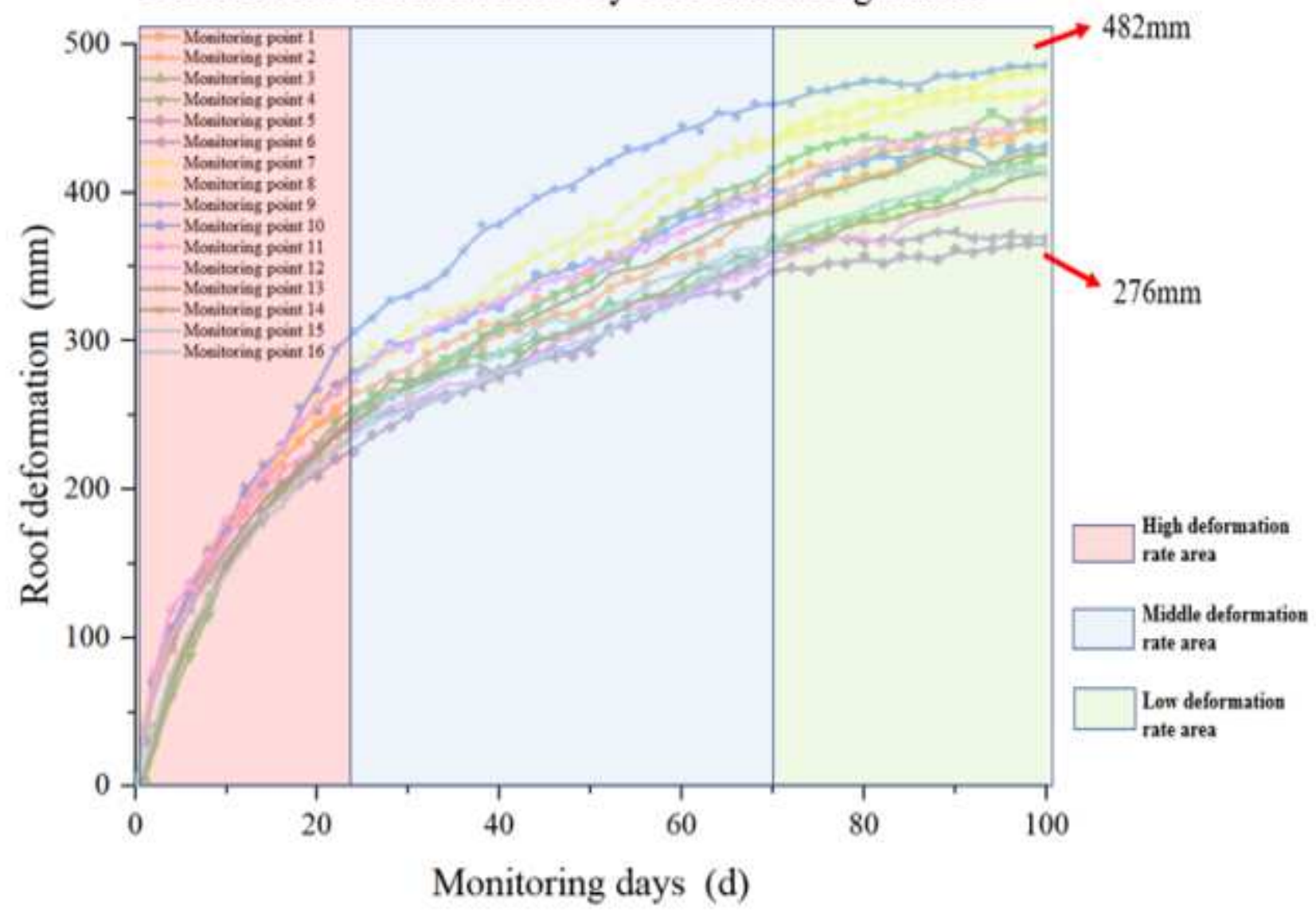

Figure 10

Monitoring diagram of the roof displacement of the text roadway 




Figure 11

Monitoring diagram of the ribs displacement of the text roadway 